\title{
Antidumping Law as Means of Facilitating Cartelization
}

Richard J. Pierce Jr

George Washington University Law School, rpierce@law.gwu.edu

Follow this and additional works at: https://scholarship.law.gwu.edu/faculty_publications

Part of the Law Commons

\section{Recommended Citation}

Pierce, Richard J. Jr, "Antidumping Law as Means of Facilitating Cartelization" (1999). GW Law Faculty Publications \& Other Works. 852.

https://scholarship.law.gwu.edu/faculty_publications/852

This Article is brought to you for free and open access by the Faculty Scholarship at Scholarly Commons. It has been accepted for inclusion in GW Law Faculty Publications \& Other Works by an authorized administrator of Scholarly Commons. For more information, please contact spagel@law.gwu.edu. 


\section{Antidumping Law as a Means of Facilitating Cartelization}

Richard J. Pierce, Jr.

While tariffs in industrial countries have come down sharply over the past half century, other barriers have become more prevalent. Administrative protection in the form of antidumping suits and countervailing duties is a case in point. While these forms of protection have often been imposed under the label of promoting "fair trade," oftentimes they are just simple guises for inhibiting competition. Typically, antidumping duties are levied when foreign average prices are below average cost of production. But that also describes a practice that often emerges as a wholly appropriate response to a softening in demand. It is the rare case that prices fall below marginal cost, which would be a more relevant standard. Antidumping initiatives should be reserved . . for those cases where anticompetitive behavior is involved. Contrary to popular notions about antidumping suits, under U.S. and WTO law, it is not required to show evidence of predatory behavior, or intent to monopolize, or of any other intentional efforts to drive competitors out of business.

Remarks of Federal Reserve Chairman, Alan Greenspan Before the Dallas Ambassadors Forum, Dallas, Texas, April 16, 1999

With that statement, Chairman Greenspan joined a large and growing chorus of critics of antidumping law. There is a consensus among economists that antidumping law interferes with pursuit of the goals of antitrust law. Antidumping law artificially increases prices by prohibiting many low cost suppliers from participating in many markets. Numerous books and articles detail this conflict between antidumping law and antitrust law. ${ }^{1}$ The point of this essay is a bit different. Antidumping law conflicts

* Lyle T. Alverson Professor of Law at George Washington University. The author was a witness for General Motors in the International Trade Commission proceeding to revoke the ferrosilicon antidumping orders that is discussed in this article. The author is indebted to the members of the George Washington University works in progress group for making helpful comments on an earlier version of this article.

${ }^{1}$ See, e.g., Gabrielle Marceau, Anti-Dumping and Anti-Trust Issues in Free Trade Areas 
with antitrust law in a more serious and direct manner. Antidumping law facilitates the formation, maintenance, and enforcement of cartels. It follows that we should either abolish antidumping law or, if that is not politically feasible, we should place a high priority on vigorous antitrust investigation of firms that seek antidumping orders.

The essay supports this hypothesis with two types of evidence: (1) a specific case in which it now has been demonstrated that three large multinational firms used a combination of antidumping complaints and threats of antidumping complaints as a means of creating and enforcing a price fixing cartel in the United States and Europe, and (2) a theory that explains why antidumping law provides an attractive means of creating and enforcing a cartel in many markets. This evidence supports the belief that there are many other as yet undetected cases in which market participants have used antidumping law with the same purpose and effect. The essay begins with a brief description of the case in which there is overwhelming evidence of use of antidumping law to facilitate cartelization. It then describes antidumping law, including its mechanics, its effects on markets, and its increasing popularity. Finally, it describes the process of creating and enforcing a cartel and the critical role that antidumping law can

(1994); Bernard Hoekman \& Michael Leidy, Antidumping and Market Disruption: The Incentive Effects of Antidumping Laws in The Multilateral Trading System: Analysis and Options for Change 155 (Robert Stern ed., 1993); Keith Anderson, Antidumping Laws in the United States: Use and Welfare Consequences, J. World Trade, Apr. 1993, at 99; Alan Deardorf, Economic Perspectives on Antidumping Law, in Antidumping Law and Practice (John Jackson \& Edwin Vermulst ed., 1991); Ranier Bierwagen, GATT Article VI and the Protectionist Bias in Anti-Dumping Laws (1990); Jagdish Bhagwati, Protectionism (1988); Richard Boltuck, An Economic Analysis of Dumping, 1987 J. World Trade L., at 45; James Brander \& Paul Krugman, A Reciprocal Dumping Model of International Trade, 15 J. Int'l. Econ. 313 (1983); Richard Dale, Anti-Dumping Law in Liberal Trade Order (1980); Melvyn Krauss, the New Protectionism: The Welfare State and International Trade (1978); Kenneth Dam, The GATT (1970); Jacob Viner, Dumping: A Problem in International Trade (1923). 
play in that process.

\section{THE ILLUSTRATIVE CASE}

In 1989, the three largest U.S. producers of ferrosilicon began to meet regularly in a hotel room at the Pittsburgh airport. ${ }^{2}$ Their goal was to create effective price fixing cartels in the U.S. and in Europe, where they also dominate production of ferrosilicon. They faced a major obstacle, however. The reduction in tariffs created by various trade treaties permitted ferrosilicon producers in Asia and South America to compete with them in the United States and Europe. ${ }^{3}$ With increased international trade in ferrosilicon, a cartel that excluded those producers would be ineffective, while a cartel that included them would be unmanageable.

The conspirators devised a clever plan to overcome this obstacle. They simply engaged in classic cartel behavior. They refused to sell at prices below the cartel price and withdrew capacity from the market. ${ }^{4}$ Because of the availability of market-priced imports from non cartel producers, this combination of actions did not immediately have its desired effect of allowing the cartel members to earn monopoly profits. It had another highly desirable effect, however. It decreased the sales of the cartel

${ }^{2}$ At the time, six firms accounted for all ferrosilicon production in the U.S. The three largest firms, representing a significant majority of U.S. ferrosilicon production, were convicted of price-fixing. Two other firms were aware of the conspiracy but were not convicted of participating in it. A smaller firm, Keokuk, apparently had no knowledge of the conspiracy. International Trade Commission Investigation No. 751-TA-21-27, In the Matter of Ferrosilicon from Brazil, China, Kazakhstan, Russia, Ukraine, and Venezuela, Publication 3218, pp. 3,10,11, 20 (Aug. 1999) [hereinafter cited as ITC Publication 3218].

3 At the time, producers in China, Kazakhstan, Russia, Ukraine, and Venezuela were selling ferrosilicon in the United States.

${ }^{4}$ ITC Publication 3218 at 16. 
members from their domestic plants and increased the sales of the market-priced imports of the noncartel producers. ${ }^{5}$ That change in the U.S. and European ferrosilicon markets provided an ideal record to support an antidumping complaint. The cartel members filed antidumping complaints in both the United States and the EEC against non cartel producers in five countries. ${ }^{6}$ The complaints of the members of the cartel were successful for reasons that will become apparent upon reading the section of this essay that describes the elements of a successful antidumping complaint. ${ }^{7}$

The antidumping countervailing duties imposed by the U.S. and the EEC had the effect of precluding the non cartel producers from five countries from competing with the cartel members in the lucrative United States and European markets. That, in turn, created a market structure in both the United States and Europe that was far more susceptible to effective cartelization. It is much easier to implement and to enforce a cartel in a market that is dominated by three large producers than in a market with a large number of producers.

A year or two later, the cartel members confronted another problem. Producers from a sixth country--Brazil--began to import ferrosilicon into the United States and Europe and to sell at prices below the cartel price. The conspirators met and agreed on a method of dealing with this new obstacle to effective cartelization. They offered the Brazilian producers a variation of the classic choice between silver and lead. They invited the Brazilian producers to join the cartel and threatened to file an
5 Id. at $10-11$.
${ }^{6}$ Id. at 12
${ }^{7}$ See text at notes 17-32 infra. 
antidumping complaint against them if they declined that kind invitation. ${ }^{8}$ When the Brazilian producers declined the invitation to join the cartel, the cartel members followed through on their threat and filed antidumping complaints against the new entrants in the United States and Europe. ${ }^{9}$ Their complaints were successful in excluding these producers from the U.S. and European markets, thereby recreating market structures that were susceptible to effective cartelization. ${ }^{10}$

This sad story has an ironic twist. The cartel members were successful in using U.S. antidumping law to create a U.S. market that was susceptible to effective cartelization, but the U.S. antidumping orders did not even have their intended effect of benefiting domestic producers and their employees. The antidumping orders precluded producers in six countries from making sales in the United States, but those imports were not replaced by increased sales by cartel members from their U.S. production facilities. The cartel members chose instead to increase the level of production of ferrosilicon from their facilities in Norway, Iceland, and Canada. ${ }^{11}$ Thus, the U.S. antidumping orders produced no increase in U.S. production of ferrosilicon. They had the effect of replacing non cartel imports that were being sold at market prices with higher priced cartel imports from other countries. ${ }^{12}$

This particular story about the use of antidumping law to facilitate violations of antitrust law has a happy ending. Someone detected the regular meetings of the cartel members in the hotel at the

${ }^{8}$ ITC Investigation No. 751-TA-21-27 at tr. p. 86 (testimony of Daniel Klett).

9 Id. at 86.

${ }^{10}$ ITC Publication 3218, at 12.

11 ITC Investigation No. 751-TA-21-27 at tr. pp. 28-29 (testimony of John Reilly)

${ }^{12}$ Id. at $28-29$. 
Pittsburgh airport and blew the whistle on the cartel. As a result, some cartel members have been found guilty and others have pleaded guilty in criminal proceedings. ${ }^{13}$ Some cartel members have been held liable in civil proceedings, while others have settled civil proceedings. ${ }^{14}$ Several more civil proceedings are still pending. ${ }^{15}$ In addition, the International Trade Commission (ITC) revoked its antidumping orders when the perjury and other serious misconduct of the cartel members was brought to its attention. ${ }^{16}$ Of course, by then, the cartel had reaped the benefits of those cartel-facilitating antidumping orders for six years.

This well-documented use of antidumping law to facilitate creation and enforcement of the ferrosilicon cartel raises an important question. How common is this use of antidumping law? There is circumstantial evidence to support the belief that it is a common pattern of behavior that is likely to increase significantly in the near future.

Antidumping law and cartelization are a perfect match. In a world of robust international trade, it is extremely difficult to create, maintain, and enforce an effective cartel without using antidumping law, but antidumping law renders the task of effective cartelization much easier to implement. Given the universal desire of all firms to eliminate competitors and to earn monopoly profits, and the ease with which firms can use antidumping law to facilitate cartelization, there is reason to believe the members of

${ }^{13}$ ITC Publication 3218, at pages 10-11.

14 ITC Investigation No. 751-TA-21-27, Response of General Motors to ITC Questions, at pages 20-22.

15 Id. at pages 20-22.

16 ITC Publication 3218. 
the ferrosilicon cartel are not unique in their choice of cartelization strategies. In order to understand the close relationship between antidumping law and cartelization, it is first necessary to understand the elements, effects, and scope of antidumping law, as well as the prerequisites to effective cartelization.

\section{ANTIDUMPING LAW}

Antidumping law varies slightly from country to country, but most other countries have based their laws and procedures on the U.S. model. ${ }^{17}$ As a result, the similarities in antidumping laws outnumber the differences. ${ }^{18}$ The typical effect of an antidumping order is to impose countervailing duties so high that producers in the target country are effectively precluded from selling in the domestic market of the country that issues the antidumping order. In order to prevail in an antidumping proceeding, a complainant must prove that its domestic operations have been injured by dumping. The causation and injury requirements are applied loosely and are regularly manipulated to support findings of causation and injury. ${ }^{19}$ Thus, the complainant's primary task is to prove "dumping." U.S. complainants are successful in proving "dumping" in over 90 per cent of cases. ${ }^{20}$ The reasons for this extraordinary rate of success become apparent once it is understood how the Department of

17 For more detailed descriptions of antidumping law, see Raj Bhala \& Kevin Kennedy, World Trade Law 489-766 (1998); Raj Bhala, Rethinking Antidumping Law, 29 G.W.J. Int'1. L. \& Econ. 1 (1995); Marceau, supra, note 1.

18 Marceau, supra, note 1, at 11-28.

19 See Bhala, supra, note 17, at 45-54; Marceau, supra, note 1, at 36-41; Ronald Cass, Causality, Coherence and Transparency in International Trade Law, in Fair Exchange (Michael Trebilcock \& Robert York eds., 1990).

20 Bhala, supra. note 17 , at 4. 
Commerce decides whether a country is engaged in illegal dumping.

An importing country engages in illegal dumping if its producers sell their products in the United States at a price that is less than either the price they charge in their home market or their cost. The two tests tend to blur as they are applied by Commerce. In comparing the United States price with the home market price, Commerce compares prices for individual sales in the United States with average prices in the home market. ${ }^{21}$ Any individual sale in the United States at a price below the average price in the home market constitutes dumping. ${ }^{22}$ In calculating the average price in the home market, Commerce excludes home market sales that it determines were made at a price below cost. ${ }^{23}$ In most cases, this has the effect of refocusing attention from a comparison between U.S. prices and home market prices to a comparison between U.S. prices and costs. ${ }^{24}$ That, in turn, means that Commerce's determination of an importer's costs is usually outcome-determinative.

Commerce uses average total cost to determine whether a producer's sales in the United States or in its home market are at prices below cost. Commerce does not use actual total cost, however. Instead, it "constructs" an average total cost figure. Commerce relies primarily on data submitted by the complainants to "construct" the foreign producer's average total cost. ${ }^{25}$ It then adds 10 per cent for

\footnotetext{
${ }^{21}$ Marceau, supra, note 1, at 11-14.

22 Bhala, supra, note 17 , at 32 .

${ }^{23}$ Id. at $35,72-73$.

${ }^{24}$ Marceau, supra, note 1, at 13-14.

${ }^{25}$ Id. at 34.
} 
overhead costs and 8 per cent for profits. ${ }^{26}$ The resulting constructed cost used by Commerce to determine whether there is illegal dumping and how much countervailing duty to impose is systematically higher than any measure of cost that is relevant to pricing decisions made by participants in most competitive markets.

Economist Alfred Kahn has stated clearly and succinctly a principle that all economists embrace: "The central policy prescription of microeconomics is the equation of price and marginal cost. ${ }^{127}$ All participants in competitive markets sell at prices based on marginal cost. ${ }^{28}$ Marginal cost consists of the amount of money a firm can save by declining to produce its last unit of production. ${ }^{29}$ Marginal cost can be either higher or lower than average cost, depending on the relationship between the current level of production and the total capacity to produce. At most levels of production, marginal cost is well below average cost, but, as the level of production approaches total productive capacity, marginal cost increases to the point at which it exceeds average cost. ${ }^{30}$ Thus, marginal cost is low in a slack market and high in a tight market.

Marginal cost does not include fixed costs, profits, or allocations of joint costs, such as overhead. ${ }^{31}$ In a slack market, marginal cost is invariably lower than average total cost, often by a large

26 Id. at 33.

271 Alfred Kahn, The Economics of Regulation 65 (1970).

${ }^{28}$ III Phillip Areeda \& Herbert Hovenkamp, Antitrust Law 221 (1996).

${ }^{29}$ I Kahn, supra, n. 27, at 65.

303 Areeda \& Hovenkamp, supra, n. 28, at 320-21.

31 Id. at 319-22. 
amount. $^{32}$ Of course, all markets fluctuate between tight and slack supply conditions. At any given point in time, there are thousands of markets that are characterized by excess capacity. In each of those markets, all participants will sell at prices that are below an accurately-determined measure of average total cost, much less the inflated measures of average total cost constructed by Commerce.

Antidumping law often is described as a way of ensuring that participants in international markets engage in fair trade. That description is demonstrably false. Antidumping law is pure protectionism. Perhaps the easiest way to understand antidumping law is to imagine how it would function if it were applied against all domestic participants in competitive markets. Even if the calculation of average total cost were accurate, the application of antidumping law to domestic firms would yield tens of thousands of determinations per year that a domestic firm is engaged in illegal dumping by selling at a price below cost. Every domestic firm that sells in a competitive market that is characterized by excess capacity would be in violation of an antidumping law that applies to domestic suppliers. Of course, that means that every firm in the United States eventually would be the subject of an antidumping order, because every market is characterized by excess capacity at some points in time. In order to believe that antidumping law is essential to assure fair trade, you would have to believe that every firm in the U.S. regularly engages in unfair trade in its role as a participant in domestic markets.

\section{ANTIDUMPING COMPARED WITH PREDATORY PRICING}

There is a widespread popular belief that the prohibition on dumping is simply the international analogue to the domestic antitrust law prohibition on predatory pricing. That belief is false. It is hard to

321 Kahn, supra note 27 , at 73-74, 84 . 
overstate the differences between the legal regime applicable to domestic market participants and the legal regime applicable to importers. ${ }^{33}$ To begin with, it is extremely difficult for a plaintiff to prevail in a predatory pricing case. The last two predatory pricing cases decided by the U.S. Supreme Court produced a summary judgment decision for the defendants ${ }^{34}$ and a judgment notwithstanding the verdict for the defendant. ${ }^{35}$ In both cases, the Court found that the plaintiff's theory was so implausible that a reasonable juror could not conclude that the defendants engaged in predatory pricing. In the Court's words: "predatory pricing schemes are rarely tried, and even more rarely successful. ${ }^{136}$

The predatory pricing theory hypothesizes a situation in which a firm sells at prices below cost for the period of time required to drive its competitors out of business and then takes advantage of its newly-acquired monopoly status to earn monopoly profits. ${ }^{37}$ The problem with the theory is to identify any situation in which predatory pricing is profitable. To come out ahead, the firm must make monopoly profits in the post predatory pricing period that exceed the losses the firm incurs during the predatory pricing period. Moreover, the firm can accomplish that goal only by charging high prices for a long period of time without attracting new market entrants that eliminate the firm's ability to earn monopoly profits. Economists are divided with respect to the viability of predatory pricing. Some believe that it is

${ }^{33}$ For a more detailed comparison of antidumping law and predatory pricing law, see Marceau, supra. note 1 , at 103-29.

${ }^{34}$ Matsushita Elec. Indus. Co. v. Zenith Radio Corp., 475 U.S. 574 (1986).

35 Brooke Group Ltd. v. Brown \& Williamson Tobacco Corp., 509 U.S. 209 (1993).

36475 U.S. at 589.

373 Areeda \& Hovenkamp, supra. note 28, at 223. 
never a viable strategy, ${ }^{38}$ while others believe that it is viable in some narrowly-defined market conditions. $^{39}$

The law prohibiting predatory pricing and the law prohibiting dumping differ in at least four critical respects: (1) measures of relevant costs; (2) attention to market structure; (3) attention to the likelihood of profitable implementation; and (4) attention to motive. Courts differ with respect to the measures of cost they use to compare a firm's prices with its costs in a predatory pricing case, but no court uses a measure of cost as high as the constructed costs Commerce uses in antidumping cases. ${ }^{40}$

Courts also look carefully at the structure of the market and the defendant's role in that market. ${ }^{41}$ If the defendant is not already the dominant firm in the market or a firm that has a realistic prospect of becoming the dominant firm in the near future, a court will not take a plaintiff's predatory pricing claim seriously. By contrast, the agencies that resolve antidumping cases do not look at all at the structure of the market or the defendant's share of the market. ${ }^{42}$ In the vast majority of successful antidumping cases, none of the foreign suppliers accounts for a dominant share of the market. A target

38 See, e.g., Frank Easterbrook, Predatory Strategies and Counterstrategies, 48 U. Chi. L. Rev. 263 (1981); Robert Bork, The Antitrust Paradox: A Policy at War with Itself 148-56 (1978); McGee, Predatory Price Cutting: The Standard Oil Case, I.J.L. \& Econ. 137 (1958).

39 See, e.g., Stephen Salop, Strategy, Predation, and Antitrust Analysis (1981); Paul Joskow \& Alvin Klevorick, A Framework for Analyzing Predatory Pricing Policy, 89 Yale L.J. 213 (1979).

40 The Supreme Court requires a showing that the defendant's price is below "some measure of incremental cost ...." 509 U.S. at 223. For a discussion of circuit court decisions, see 3 Areeda \& Hovenkamp, supra. note 28, at 228-32, 238-44, 317-57, 367-425.

${ }^{41}$ See 3 Areeda \& Hovenkamp, supra. note 28, at 226-27, 236-38, 245-53.

42 See Marceau supra. note 1, at 110-17. 
country rarely accounts for more than 20 per cent of the U.S. market. A predatory pricing theory would be laughable on those facts.

Courts also look with care at the question whether the defendant has a realistic prospect of recovering its losses, plus a profit, in the post-predatory pricing period. ${ }^{43}$ That, in turn, requires the court to look at the structure of the market, the defendant's share of the market, and the barriers to entry in the market. If the defendant has no realistic prospect of recovering its losses and still coming out ahead, the court will grant summary judgment for the defendant. The agencies that implement antidumping law do not look at those factors at all. ${ }^{44}$

Finally, courts will require the plaintiff to make a plausible showing that the defendant has a motive to engage in predatory pricing. ${ }^{45}$ This requires a careful evaluation of the likely level of losses the defendant will absorb through predatory pricing, the likely period of time required to drive its competitors out of business, and the likely level of monopoly profits the defendant will then earn before its monopoly pricing attracts new entrants into the market. If the plaintiff cannot prove that it is at least plausible that the defendant can profitably implement predatory pricing, a court will not infer a motive to engage in predatory pricing.

By contrast, the agencies that implement antidumping law do not look at motive at all. ${ }^{46}$ In the

43 See3 Areeda \& Hovenkamp, supra. note 28, at 254-317.

44 See Marceau, supra. note 1, at 110-17.

45 See E. Thomas Sullivan \& Herbert Hovenkamp, Antitrust Law, Policy \& Procedure 748-53 (4th ed. 1999).

46 See Marceau, supra. note 1, at 110-117. 
vast majority of cases, the "dumping" the agencies find cannot possibly be motivated by a desire to maximize profits, even though that desire is virtually ubiquitous in the wake of the collapse of communism and the widespread privatization of previously state-owned production facilities. It is appropriate to be skeptical of a legal regime that implies that hundreds of corporations are attempting to commit economic suicide every year. In short, it is doubtful that a single one of the hundreds of successful antidumping complaints that have been filed against importers would have produced a decision for the plaintiff if it had been brought as a predatory pricing complaint against a domestic competitor.

\section{THE GROWING IMPORTANCE OF ANTIDUMPING LAW}

Antidumping law has existed for a century, but it has become increasingly important in recent years. ${ }^{47}$ Ironically, the use and importance of antidumping law is inversely related to the prevalence and efficacy of free trade agreements. As free trade agreements have reduced tariffs and outlawed most import quotas, antidumping cases have increased dramatically. ${ }^{48}$ Over the last fifty years, the average tariff level has fallen from 40 per cent to 3.9 per cent, and 43 per cent of goods are now exempt from all tariffs. ${ }^{49}$ Over the same period of time, the number of successful antidumping cases filed in the United States alone has increased a staggering 2500 per cent $^{50}$ The geographic scope of antidumping

47 Id. at 7-8.

48 General Accounting Office, The General Agreement on Tariffs and Trade 2-5 (1994); Bhala, supra. note 17 , at 3-5.

49 Id. at 3.

50 During the period 1958-1965, the United States issued about one antidumping order per year. See Bela Belassa, Studies in Trade Liberalization 298 (1967). By 1990, the United States was 
laws also has increased dramatically. Until 1990 antidumping cases were confined almost entirely to the United States, Canada, Australia, and the European Union. ${ }^{51}$ Since 1990 many other countries have enacted antidumping laws, and domestic firms in other countries are making liberal use of those laws, often with the effect of excluding U.S. firms from those countries' markets. ${ }^{52}$

This powerful inverse relationship between free trade agreements and antidumping actions is easy to explain. As domestic market participants around the world lose access to their traditional protectionist weapons -- tariffs and import quotas -- they find that they have only one protectionist weapon left -- an antidumping action. That weapon is at least as potent as the traditional weapons, however, so they use it liberally and with great success.

Even politicians who profess to have a deep belief in free trade love antidumping law. Thus, for instance, the 1993 Uruguay Round of Multilateral Trade Negotiations produced enormous reductions in permissible tariffs and import quotas, ${ }^{53}$ but it also explicitly legitimized antidumping actions, subject only to minor limitations of highly uncertain effect. ${ }^{54}$ Similarly, Presidents Kennedy, Reagan, Bush, and

issuing about 25 antidumping orders per year. See Anderson, supra. note 1, at 102.

51 See Bryan Johnson, A Guide to Antidumping Law: America's Unfair Trade Practice 5 (Heritage Foundation 1992).

52 Bhala, supra. note 17, at 4. See, e.g., Norso Komuro, Japan's First Antidumping Measures in the Ferro-Silico-Manganese Case, J. World Trade 5 (June 1, 1993); Eduardo Andre, The Mexican Antidumping Regime, J. World Trade 5 (April 29, 1993).

${ }^{53}$ For the text of the treaty, see 33 International Legal Materials 1130 (1994). For detailed analysis of the treaty, see Bhala \& Kennedy, supra. note 17.

${ }^{54}$ For a summary of the Uruguay Round criteria applicable to antidumping actions, see Marceau, supra. note 1, at ix1-x11. For a detailed analysis of those criteria, see Bhala, supra. note 17, at 55-125. There is a concensus that the changes in antidumping law required by the Uruguay Round 
Clinton repeatedly expressed their enthusiastic support for free trade and lobbied Congress to ratify several important trade treaties. Yet, the level of antidumping orders issued increased dramatically throughout the Kennedy, Reagan, Bush, and Clinton Administrations. ${ }^{55}$

Politicians like antidumping law for several related reasons. First, and most important, antidumping law permits politicians to appear to support free trade while they preserve their discretion to engage in ad hoc protectionism at the behest of constituencies with political clout. Second, supporting simultaneously free trade and antidumping law allows a politician to take the rhetorical high ground. Most people understand the value of free trade, but nobody likes "dumping." The word conjures up an image of an evil foreign corporation that is using the United States as a toxic waste dump. Third, few members of the electorate are likely to do the hard work required to understand the simple reality that the conduct that is prohibited by antidumping law is the normal, socially-beneficial conduct of any participant in a competitive market and, conversely, that antidumping law is just as protectionist as high tariffs and low import quotas.

As of 1999, over 200 U.S. markets were affected by antidumping orders. ${ }^{56}$ There is reason to believe that a high proportion of those markets, like the ferrosilicon market, were cartelized with the aid of antidumping orders. To explain the basis for that belief, this essay will turn next to a discussion of the process of cartelization.

are unlikely to reduce protectionist use of antidumping law. See Bhala, supra. note 17, at 55; Marceau, supra. note 1 , at $\mathrm{x} 1$.

55 See Marceau, supra. note 1, at 7-10; Anderson, supra. note 1, at 102.

56 Anderson, supra. note 1, at 102. 


\section{CARTELIZATION}

In the absence of antidumping orders, it is difficult to create, maintain, and enforce a price-fixing cartel. ${ }^{57}$ The goal of a cartel is the same as the goal of a monopolist -- to restrict output artificially in order to charge an artificially high price in order to earn monopoly profits. ${ }^{58}$ The problem is that the members of the cartel must share the output restrictions in order to earn the monopoly profits. Each member would prefer that the other members implement the output restrictions, thereby maximizing that member's share of the monopoly profits. The cartel members must negotiate a mutually acceptable allocation of output limits that will create a mutually acceptable allocation of monopoly profits. That is difficult because each member has a different supply curve and a different mix of production facilities. ${ }^{59}$ Moreover, each member knows its own supply curve better than the supply curves of the other members. Each member suspects that the other members are misrepresenting their supply curves. Thus, the negotiating process is plagued by information asymmetries. ${ }^{60}$

57 See generally 2A Phillip Areeda, John Solow \& Herbert Hovenkamp, Antitrust Law 24-26 (1995); Ernest Gellhorn \& William Kovacic, Antitrust Law and Economics 157-164 (4th ed. 1994); Frank Scherer \& David Ross, Industrial Market Structure and Economic Performance 239-244 (3rd ed. 1990); R. Blair \& Kasserman, Antitrust Economics 132-153 (1985); Adelman, Is the Oil Shortage Real, 9 For. Pol. 69 (1973); Paul MacAvoy \& Orr, Price Strategies to Promote Stability, 32 Economica 186 (1965); Paul MacAvoy, The Economic Effects of Regulation. (1965); George Stigler, A Theory of Oligopoly, 72 J. Pol. Econ. 77 (1964); Donald Dewey, Monopoly in Economics and Law 7-24 (1959); Stocking \& Watkins, Cartels in Action (1947); Patimkin, Multiple Plant Firms, Cartels and Imperfect Competition, 61 Q.J. Econ. 173 (1947).

58 Gellhorn \& Kovacic, supra. note 57, at 157.

59 Scherer \& Ross, supra. note 57, at 239-44.

${ }^{60}$ See generally Oliver Williamson, Transactions Cost Economics: The Governance of Contractual Relations 22 J.L. \& Econ. 233 (1979). 
Reaching initial agreement on an allocation of output restrictions is only the beginning of the process of effective cartelization. The members must periodically revise the allocation of output restrictions in response to changes in market conditions. They also must devise and implement a method of detecting and punishing violations of cartel rules. Every member of a cartel has a powerful incentive to negotiate a set of cartel rules and then to cheat. ${ }^{61}$ In most circumstances, the members of the cartel must accomplish each of these difficult tasks in secret, because they are usually violating civil and criminal laws.

There are three factors that are particularly important predictors of the likely success of an attempt to cartelize a market -- degree of product homogeneity, structure of the market, and the role of government. It is much easier to cartelize a market that is characterized by high product homogeneity than it is to cartelize a market that is characterized by high product heterogeneity. ${ }^{62}$ A homogenous product market can be governed effectively by a single, relatively simple set of output and pricing rules. A heterogenous product market requires a much more complicated set of rules applicable to products with different characteristics. Those rules are more difficult to negotiate, to renegotiate in response to changes in market conditions, and to enforce.

Market structure is a critical determinant of the likelihood of successful cartelization. ${ }^{63}$ A cartel can be effective without including every producer, but its relative efficacy declines as the percentage of

${ }^{61}$ See Ian Ayres, How Cartels Punish: A Structural Theory of Self-Enforcing Collusion, 87 Colum. L. Rev. 295 (1987).

${ }^{62}$ IIA Areeda, Solow \& Hovenkamp, supra. note 57, at 13-14.

63 Id. at 15. 
the market that it controls declines. Thus, one important cartel goal is to recruit every producer that accounts for a significant share of the market. This goal often conflicts with another cartel goal, however. The smaller the number of members of a cartel, the easier it is to create, maintain, and enforce the cartel. ${ }^{64}$ Thus, if a market consists of five firms that account for 90 per cent of the market, it is a good candidate for cartelization. Even three or four of those firms may be able to create an effective cartel. Conversely, a market that consists of fifteen firms with approximately equal market shares is a poor candidate for cartelization. The number of firms that must join the cartel to make it effective is too large to enable the members to reach agreement on initial allocations of supply restrictions and to renegotiate those allocations as market conditions change. The risk of member cheating also increases as the number of members of a cartel increases. ${ }^{65}$

The existence of potential new market entrants is another important structural predictor of likely success in an attempt to cartelize a market. ${ }^{66}$ A cartel is unlikely to be effective if non-cartel producers are in a position to take a large share of the market from cartel members by entering a cartelized market and charging prices below the cartel price. Yet, recruiting potential entrants to join the cartel greatly complicates the task of managing the cartel.

The role of governments is the final major predictor of successful cartelization. In most market contexts, governments enact and enforce antitrust laws that forbid cartelization. The existence of vigorously enforced antitrust laws greatly complicates the tasks of creating, maintaining, and enforcing a

\footnotetext{
${ }^{64}$ 2A Areeda, et al., supra. note 57, at 15, 24-26.

65 See Ayres, supra. note 61.

66 2A Areeda, Solow \& Hovenkamp, supra. note 57, at 15.
} 
cartel. Those laws also deter efforts at cartelization by exposing the participants to potential criminal and civil liability.

Governments also can play critical roles in facilitating effective cartelization. The most effective and durable cartels in history owe most of their success to governmental efforts to facilitate the cartel. ${ }^{67}$ Thus, for instance, most large countries, including the United States, have had effective cartels in numerous agricultural product markets for over half a century, even though those markets have structures that render them poor candidates for effective cartelization. ${ }^{68}$ The government can play a major role in facilitating a cartel by using its police powers to coerce unwilling market participants into joining a cartel, to coerce members into accepting cartel rules that they oppose, to detect violations of cartel rules, and to punish violations of cartel rules. Sometimes the same government plays multiple inconsistent roles related to the cartelization process. Thus, for instance, during the 1970s, the Canadian Government purported to be enforcing its antitrust laws vigorously, at the same time that it organized and enforced an international uranium cartel that was successful in increasing the price of uranium by 600 per cent..$^{6}$

\section{CARTELS AND INTERNATIONAL TRADE}

${ }^{67}$ See George Stigler, The Theory of Economic Regulation, 2 Bell J. Econ. \& Management Sci. 3 (1971).

68 See, e.g., Parker v. Brown, 317 U.S. 341 (1943) (upholding California raisin cartel); Minnesota Milk Producers Ass'n v. Glickman, 153 F. 3d 632 (8th Cir. 1998) (upholding Department of Agriculture's method of implementing national milk cartel.)

69 See Charles Goetz \& Fred McChesney, Antitrust Laws: Interpretation and Implementation 77-89 (1998). 
Robust international trade renders cartelization far more difficult. International trade has increased fourteen fold over the last fifty years. ${ }^{70}$ As Chairman Greenspan noted in his Dallas speech, this increase in international trade is linked closely to increased prosperity attributable to increased competition:

The evidence is overwhelmingly persuasive that the massive increase in world competition -- a consequence of broadening trade flows -- has fostered markedly higher standards of living for almost all countries who have participated in cross-border trade. I include most especially the United States. ${ }^{71}$

International trade greatly complicates the task of creating effective cartels in several ways.

First, international trade reduces the degree of concentration of many markets. Thus, for instance, two decades ago the three U.S. automakers were referred to as the "big three" for good reason. They dominated the U.S. market. Now they share the U.S. market with numerous effective foreign rivals. This phenomenon has been replicated in thousands of markets around the world, often with U.S. firms as the primary seller-beneficiaries and always with consumers as beneficiaries. A market with ten sellers is much more difficult to cartelize than a market with three sellers.

International trade also increases significantly the likelihood that one or more non cartel members will enter a cartelized market. In the context of many markets, the potential new entrants include firms in many countries. Credible threats of entry can be a powerful deterrent to cartelization.

The greatly increased cultural heterogeneity of firm managements creates an added obstacle to effective cartelization. It is easier for five U.S., or five German or Japanese, CEOs to reach agreement

${ }^{70}$ Remarks by Chairman Alan Greenspan Before the Dallas Ambassadors Forum, Dallas, Texas, Apr. 16, 1999. 
with respect to cartel rules than it is for five CEOs who do not share the same culture to reach agreement.

Increased international trade also reduces the potential for governments to facilitate cartelization for several reasons. First, if the sources of supply for a market are widely distributed among several nations, no national government has a strong incentive to facilitate cartelization of the market. Second, if the sources of supply are distributed among several nations, no national government can use its police powers alone to facilitate effective cartelization. It must either reach agreements with the other nations that include significant supplies or use its military power to enforce the cartel. The history of cartelization includes examples of both of those phenomena, ${ }^{72}$ but both are difficult and costly to implement. As the number of nations that account for supplies to a market increases, the difficulty of either maintaining an effective consensual multinational cartel or of using military force to enforce a unilateral international cartel increase exponentially.

\section{CARTELIZATION AND ANTIDUMPING LAW}

Antidumping law facilitates the process of creating, maintaining, and enforcing a cartel in many ways, most of which are demonstrated by the ferrosilicon case. First, it is easier to pursue a successful antidumping complaint in a homogeneous product market than in a heterogeneous product market. Thus, antidumping law is most readily available in the context of markets that are particularly susceptible to effective cartelization.

${ }^{71}$ Id.

${ }^{72}$ For an example of a multinational cartel, see John Enders, OPEC and the Industrial Countries: The Next Ten Years, 53 For. Aff. 625 (1975). For an example of use of military force to 
Second, a successful antidumping action can reduce the number of sellers in a market and increase significantly the degree of concentration of the market. Thus, for instance, the ferrosilicon antidumping orders eliminated numerous sellers from the United States and European markets, leaving markets that were dominated by the three cartel members.

Third, an antidumping action can facilitate successful cartelization by reducing the cultural heterogeneity of the firm managements that must reach agreement in order to implement a cartel. Thus, for instance, the ferrosilicon antidumping orders eliminated all firms in Asia and Latin America, leaving only North American and European firms in the United States and European markets.

Fourth, for the same reason, antidumping actions make it much more likely that one or a few governments will engage in intentional, surreptitious efforts to facilitate cartelization. There is no evidence to suggest that any government intentionally played that type of role with respect to the ferrosilicon cartel, but the Eighth Circuit recently concluded that the provincial government of Saskatchewan responded to U.S. antidumping orders by adopting legislation that had the effect of cartelizing the U.S. potash market and increasing the price of potash by 60 percent. $^{73}$

Fifth, an antidumping action, or the threat of an antidumping action, can deter non cartel members from attempting to enter the cartelized market. The members of the ferrosilicon cartel first tried to deter Brazilian producers from entering the U.S. market by threatening them with an antidumping action. When that threat was ineffective, the cartel members used a successful antidumping

enforce a cartel, see American Banana Co. v. United Fruit Co., 213 U.S. 347 (1909).

73 See Blomkest Fertilizer, Inc. v. Potash Corp. of Saskatchewan, 176 F.3d 1055, 1059 (8th Cir. 1999). 
action to exclude Brazilian producers from the market. Of course, the threat to file an antidumping order against a new market entrant need not be explicit to be effective. A potential new entrant to a market that already has been the subject of antidumping orders may logically infer that its entry into the market will elicit an antidumping complaint even in the absence of an explicit threat.

Sixth, a cartel can use antidumping actions or threats of antidumping actions as means of enforcing a cartel. Again, the ferrosilicon cartel's treatment of Brazilian producers illustrates the point. When the Brazilian producers refused to join the cartel or to adhere to the cartel rules, the cartel members simply removed the producers from the market by filing an antidumping action.

Finally, it should be apparent that antidumping law is a means through which governments can, and do, use their police powers to facilitate the formation, maintenance, and enforcement of cartels. In most cases, however, the agencies that implement antidumping law are unaware of this effect of their actions.

\section{THE LEGAL CARTEL ALTERNATIVE}

The conduct of the members of the ferrosilicon cartel has an obvious downside. There is some chance that the participants in such an illegal cartel will be caught and punished, as they were in the ferrosilicon case. I suspect that the risk of getting caught and punished at present is too low to be an effective deterrent, given the enormous financial gains attributable to an antidumping-facilitated cartelization of a market, but it is a non-trivial risk that undoubtedly would deter some firms from replicating the behavior of the members of the ferrosilicon cartel. In many situations, however, a small group of firms can engage in a pattern of behavior that is equivalent in its effects to the conduct of the members of the ferrosilicon cartel, but that does not expose the firms to any risk of civil or criminal 
liability.

The critical step in this legal variation on the theme is the same as the critical step that was taken by the members of the ferrosilicon cartel. The three firms that desire to cartelize a market meet to discuss the possibility of filing a joint antidumping complaint against virtually all of the other sellers in the market. They must structure their discussions carefully to avoid violating the antitrust law. They cannot discuss their own prices or costs in their meeting, but they certainly can discuss the prices and costs of the competitors they want to exclude from the market. Those discussions, and the ensuing joint antidumping complaint, are within the scope of the Noerr-Pennington exclusion from antitrust liability. ${ }^{74}$ Indeed, the Third Circuit has held that the Noerr-Pennington doctrine insulates firms from antitrust liability even if they intentionally misrepresent facts in an antidumping complaint. ${ }^{75}$

Once the three firms have used antidumping law to exclude most of their competitors from the market, they can implement a "legal cartel" by engaging in conscious parrallelism, i.e., each firm makes its output and pricing decisions based on its knowledge of its competitors' prices and costs and its observations and expectations with respect to the behavior of its competitors in various market conditions. ${ }^{76}$ Conscious parrallelism is not a violation of antitrust law ${ }^{77}$ and it is easy to implement in a

74 See United Mine Workers v. Pennington, 381 U.S. 657 (1965); Eastern Railroad Presidents Conference v. Noerr Motor Freight, 365 U.S. 127 (1961). See also Einer Elhauge, Making Sense of Antitrust Petitioning Immunity 80 Cal. L. Rev. 1177 (1992).

75 Cheminor Drugs, Ltd. v. Ethyl Corp., 168 F.3d 119 (3d Cir. 1999).

76 See Richard Posner Oligopoly Price and the Antitrust Laws: A Suggested Approach, 21 Stan. L. Rev. 1562 (1969); Donald Turner, The Definition of Agreement Under the Sherman Act: Conscious Parallelism and Refusals to Deal, 75 Harv. L. Rev. 655 (1962).

77 Brooke Group Ltd. v. Brown \& Williamson Tobacco Corp., 509 U.S. at 227; Theatre 
highly concentrated market for a homogeneous product. ${ }^{78}$ The three members of this "legal cartel" also would greatly benefit from the vast amount of information they obtained about each other's costs and prices during the antidumping proceeding.

\section{CONCLUSION}

Antidumping law has no good effects and many bad effects, including facilitation of attempts to cartelize markets. Professor Marceau has proposed the most appealing solution to this problem. ${ }^{79}$ She would replace antidumping law with domestic antitrust law. In Marceau's proposed legal regime, an importer could be excluded from a market for "dumping" only when a domestic participant could be excluded for predatory pricing. My colleague, Professor Bhala, agrees with Marceau on the merits, but he is skeptical that politicians will ever be willing to relinquish their discretion to engage in opportunistic ad hoc protectionism at the behest of powerful constituencies. ${ }^{80}$ He urges a new, less destructive method of implementing antidumping law as a second best solution. ${ }^{81}$ If neither of those alternatives proves to be viable, I propose a third best solution.

Antitrust authorities should routinely conduct a thorough investigation of the conduct of every

Enterprises, Inc. v. Paramount Film Distributing Corp., 346 U.S. 537, 540-541 (1954).

78 Alexis Jaquemin \& Margaret Slade, Cartels, Collusion, and Horizontal Mergers, in 1 Handbook of Industrial Organization 415 (Richard Schmalensee \& Robert Willig, eds 1989); See George Hay \& Daniel Kelley, An Empirical Survey of Price Fixing Conspiracies, 17 J. L. \& Econ. 13 (1974).

\footnotetext{
79 Marceau, supra. note 1.

${ }^{80}$ Bhala, supra. note 17 , at 8-24.

${ }^{81}$ Id. at 125-142.
} 
firm that files an antidumping complaint. The high potential to use antidumping law to facilitate cartelization justifies a significant allocation of antitrust enforcement resources to markets that are subject to antidumping orders. It might seem superficially strange that one agency would use the legally authorized actions of another agency to trigger an investigation of potential illegal conduct facilitated by the agency's actions, but a national government includes many agencies whose statutory missions and cultures are often in tension. Some agencies -- most notably the Departments of Agriculture and Commerce -- have often encouraged cartelization and are required by statute to take actions that facilitate cartelization. Other agencies -- most notably the Department of Justice and the Federal Trade Commission -- dislike cartels and have a statutory duty to detect and punish those who attempt to create cartels. They can fulfill their responsibilities most effectively by investigating the conduct of anyone who files an antidumping complaint. The conduct leading to, and including, the filing of the antidumping complaint is shielded by the Noerr- Pennington doctrine, but any associated agreements to fix prices or limit output are violations of antitrust law. 